\title{
Leaf-mold for Soil Improvement in Home Gardens
}

By David E. Hill

RECEIVED

$$
\text { SEP - } 11978
$$

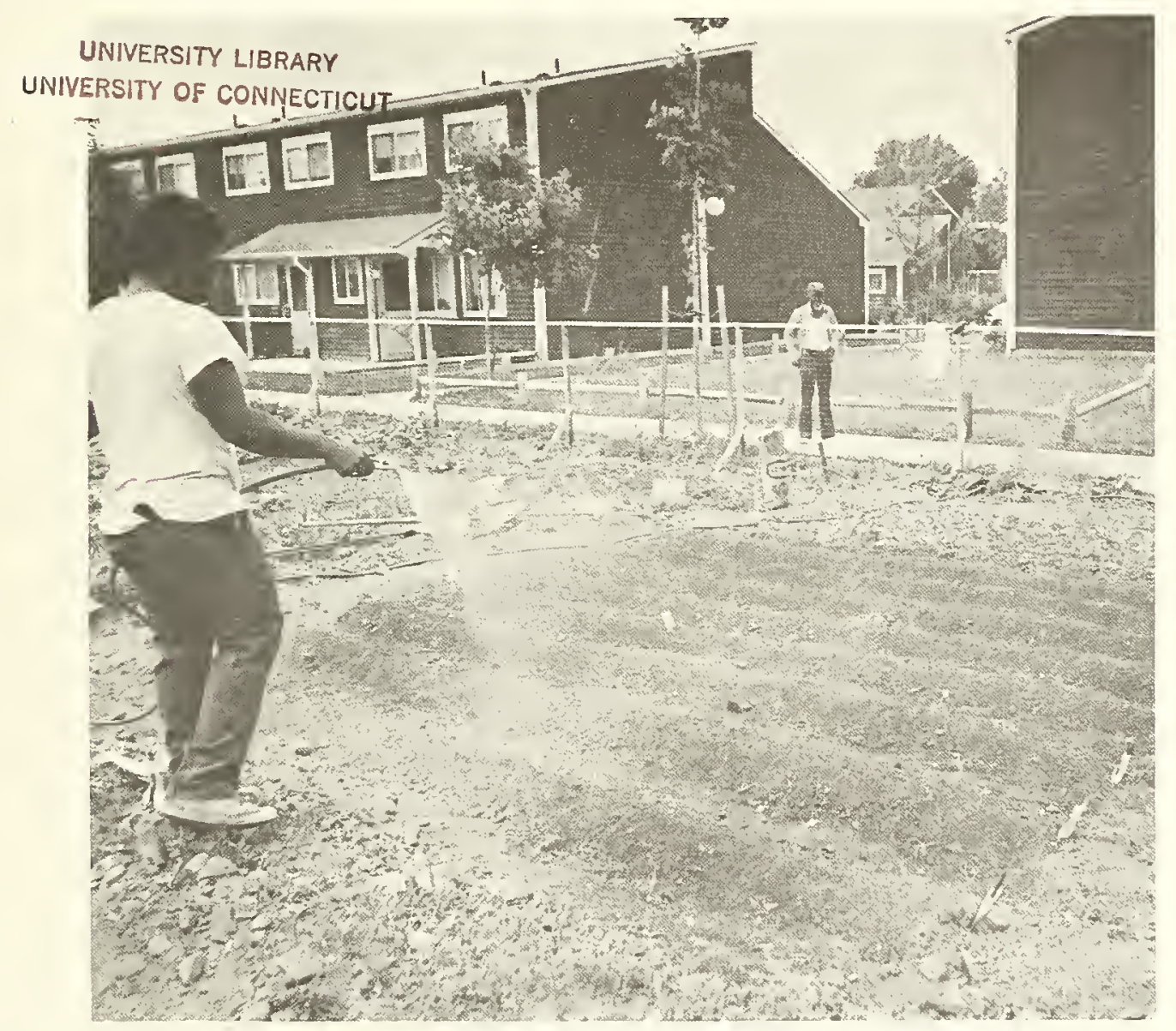

Planting time at the Day-Waverly Community Gardens 


\section{FOREWORD}

Community gardens springing from rubble-strewn vacant lots are a welcome sign that not all agricultural land lost to the growth of megalopolis is land lost forever.

A recent Gallup poll conducted for Gardens for All, a national association for gardening, estimates that 32 million households in the United States had vegetable gardens in 1977. Gallup also reports that two million garden plots were in organized community gardens. Connecticut had over 7,000 community plots in 1977; more are planned for this year. Thus, back-yard agriculture in cities and their suburbs has a real effect on family diets and budget.

Our participation in the Day-Waverly Gardens in New Haven at the request of the Greater New Haven Arts Council provided an outdoor laboratory where we could test techniques for improving the moisture-holding capacity and yields on very droughty soils. We not only measured increased yields from leaf-mold but also demonstrated that local production of leaf-mold was feasible using leaves from New Haven's autumn street collections. But best of all, we observed a rekindling of the human spirit and of all the amenities that accompany community effort. These kinds of experiments reaffirm our commitment to increase the production of food wherever it can be grown.

\section{Paul E. Waggoner}

Director 


\title{
Leaf-mold for Soil Improvement in Home Gardens
}

\author{
By David E. Hill
}

Some soils in Connecticut are marginal for crop production because they do not hold enough water for adequate plant growth. Little water is available from very sandy soils because they contain few small pores to hold water against gravitational pull. Such soils drain rapidly, allowing water to seep beyond the reach of plant roots. In soils underlain by bedrock at depths of $12-15$ inches, root growth is restricted and plants can only use the limited water held in that shallow zone. These droughty soils are common in Connecticut's valleys and ridges. Farmers avoid these marginal soils that require large additions of organic matter or expensive irrigation. But droughty soils are often found in backyards where gardens are faithfully tended despite their limitations. The success of the gardener of droughty soil depends on his ability to overcome moisture limitations.

The epitome of droughtiness in soil is found in vacant lots within Connecticut's cities. Here, houses have been razed and their cellar holes filled with a mixture of sand, brick, mortar, and other urban artifacts. Such vacant lots have recently become sites for community gardens. The sponsor of one such garden, the Greater New Haven Arts Council, came to the Experiment Station with the challenge of improving the droughty soil in an inner city community garden. This request led to experiments in 1976 in improving the moisture-holding capacity of the droughty soil used for the community gardens in New Haven.

Based on the results of this first year of research, the garden was amended with leaf-mold in 1977 and experiments were conducted to determine the effects of the rate and timing of fertilization on yields. Similar experiments were conducted at Lockwood Farm in Mt. Carmel with various rates of application of leaf-mold on a shallow droughty soil underlain by bedrock. These experiments also allowed estimation of the economic yield that can be expected from a garden supplied with optimai fertilizer and water.

Site and soil

\section{METHODS}

The Day-Waverly Conmunity Gardens are a few blocks from the center of New Haven in a corridor cleared of houses in the mid-1960's in anticipation of reconstruction of Connecticut Route 34. The land, which had been idle for 10 years, had accumulated great quantities of debris and demolition waste. After the New Haven Department of Public Works removed surface debris, the 3/4-acre lot was plowed. Plowing is more efficient than rototilling in breaking up extreme compaction and buried brick, mortar and concrete. About 60 families then toiled to remove the debris dislodged by the plow. The Experiment Station conducted experiments in a $20 \times 40$-foot area of the garden.

The sandy, coarse textured soil had a low moisture holding capacity. Its native fertility was low. The neutral pH (6.9) was due to mortar in the soil. An unique feature of this site is its extended growing season. There are almost 40 more frost-free days in urban New Haven than in suburban Mt. Carmel (Havens and McGuire, 1961). In 1977 planting dates were about a week earlier at the urban site and the 
first killing frost was about 10 days later than at Mt. Carmel. Thus, the growing season was about 2.5 weeks longer in the city.

The experimental plots at Lockwood Farm were in a flat field at the broad crest of a low drumloidal ridge. The loamy soil has been mapped as Yalesville fine sandy loam by the Connecticut Cooperative Soil Survey. The most notable characteristic of this soil type is its weakly cemented bedrock at a depth of 20 to 40 inches. However, the bedrock in the vicinity of the plots is only 12-14 inches below the surface. Thus, the soil must be classified as a taxadjunct of the Yalesville series. The area used for the experimental plots was divided into four $10 \times 30$-foot plots. The medium textured soil has a moderate moisture holding capacity, but its storage potential is limited by its shallow depth. The characteristics of the soil at both sites are given in Table 1.

\section{Soil amendments}

Initial evaluation of the Day-Waverly Community Gardens site clearly indicated that the moisture holding capacity of the very sandy soil would limit the growth of vegetables. Among the means available to overcome this problem are green manure crops dug into the garden soil. The resulting increases in soil organic matter and in soil moisture retention are modest, short lived, and require repeated application (Downs et al., 1962). We were seeking a more permanent solution, so we tested several methods in 1976. On one $10 \times 20$-foot plot, 3 inches of well decomposed leafmold was rototilled to a depth of 6 inches. On a second plot, 6 inches of a finer textured topsoil was spread on top of the native sandy soil. $\ln$ a third plot, four sheets of newspaper were buried 0.5 inch below the surface of the native soil to reduce evaporation. These were placed between the rows of plants after seeds had germinated and seedlings had recovered from the shock of transplanting. A fourth, untreated plot served as a control. All plots were fertilized as needed based on soil tests (Lunt et al., 1950); the leafmold and topsoiled plots received $4 \mathrm{lbs}$ of 10-10-10 fertilizer; the paper-mulched and control plots received $6 \mathrm{lbs}$ of 10-10-10 fertilizer. The topsoiled plot received $6 \mathrm{lbs}$ of ground limestone. The other plots received none because of the high $\mathrm{pH}$ of the sandy fill. The leaf-mold plot needed an additional $3 \mathrm{lbs} 10-10-10$ fertilizer in mid-July. The other plots had medium to medium-high levels of N, P, and $\mathrm{K}$ in mid-July. Thus, no additional fertilizer was required.

ln 1976, leaf-mold appeared to be a promising and econo. mical amendment, but some nutrient deficiencies were noted. Thus, we turned our attention in 1977 to rates and timing of fertilization. The plots were modified as follows: Topsoil was removed from the topsoiled plot to expose the sandy soil. Most of the newspaper mulch had disintegrated but what remained was removed. These plots and the control plot then received 3 inches of leaf-mold and were rototilled to a depth of 6 inches. The leaf-mold plot remaining from 1976 received no additional leaf-mold. The plots received 6,8 , and $11 \mathrm{lbs}$ fertilizer in 1,2 , and 3 applications respectively. The dates and rate of application of 10-10-10 fertilizer are reported in Table 2.

Table 2. Rate and time of 10-10-10 fertilizer applications.

\begin{tabular}{lccc}
\hline & \multicolumn{3}{c}{ Plot } \\
\cline { 2 - 5 } Date & $\begin{array}{c}\text { Applications } \\
(1.8 \times)\end{array}$ & $\begin{array}{c}\text { 2 Applications } \\
(1.3 \times)\end{array}$ & $\begin{array}{c}\text { 1 Application } \\
(\times)\end{array}$ \\
May 4 & 6 & 6 & 6 \\
June 3 & 2 & 2 & - \\
July 11 & 3 & - & - \\
Total & 11 & 8 & 6 \\
\hline
\end{tabular}

The $10 \times 30$-foot plots at Lockwood Farm were amended with 1,2, and 3 inches of leaf-mold and rototilled to a depth of 6 inches. A fourth plot without leaf-mold served as a control. Each plot received $6 \mathrm{lbs}$ 10-10-10 fertilizer. Ground limestone was added in varying amounts as indicated by soil tests. The 3 -inch leaf-mold plot received $9 \mathrm{lbs}$; the 2 -inch plot received $12 \mathrm{lbs}$; the 1 -inch plot received 15 $\mathrm{lbs}$; and the control plot received $21 \mathrm{lbs}$ limestone to bring the $\mathrm{pH}$ of all plots to an optimum 6.5. Soils were tested frequently to insure that plant nutrients were in adequate supply. Fertilizer was added to the portions of the plots planted to fall crops. The third planting of beans received

Table 1. Characteristics of sites and soils.

\begin{tabular}{lcc}
\hline Location & Day-Waverly Gardens & Lockwood Farm \\
Physiography & Downtown New Haven & Mt. Carmel \\
Parent material & Glacial outwash terrace & Drumloidal hill \\
Depth to bedrock (inches) & Sandy builder's fill & Loamy glacial till \\
Elevation above m.s.l. (feet) & $>120$ & $12-14$ \\
Climate: (Havens \& McGuire, 1961) & 40 & 200 \\
$\quad$ Average last frost of spring & April 12 & May 2 \\
Average first frost of fall & October 26 & October 7 \\
Average frost free days & 197 & 158 \\
Soil series & Unnamed & Yalesville taxadjunct \\
Texture & Loamy coarse sand & Loam/fine sandy loam \\
$\%$ sand & 76 & 51 \\
$\%$ silt & 22 & 41 \\
clay & 2 & 8 \\
Volume coarse fragments (range) & $18-40$ & $5-15$ \\
pH & 6.9 & 5.5 \\
Plot size (feet) & $14)$ & $(4) 10 \times 30$ \\
Total square feet & 800 & 1200 \\
\hline
\end{tabular}


Table 3. Physical properties of the garden plots.

\begin{tabular}{|c|c|c|c|c|c|}
\hline \multirow[b]{2}{*}{ Treatment } & \multirow[b]{2}{*}{$\begin{array}{c}\text { Organic } \\
\text { Matter } \\
\%\end{array}$} & \multirow[b]{2}{*}{$\begin{array}{c}\text { Volume } \\
\text { Stones } \\
\%\end{array}$} & \multicolumn{2}{|c|}{ Inches of Water at } & \multirow{2}{*}{$\begin{array}{l}\text { Inches of } \\
\text { water } \\
\text { available } \\
\text { to plants }\end{array}$} \\
\hline & & & $\begin{array}{l}\text { Field } \\
\text { Capacity }\end{array}$ & $\begin{array}{l}\text { Wilting } \\
\text { Point }\end{array}$ & \\
\hline \multicolumn{6}{|c|}{ Day-Waverly Gardens } \\
\hline Leaf mold & 16.1 & 18 & 1.9 & 0.6 & 1.3 \\
\hline Topsoil & 4.0 & 10 & 1.2 & 0.5 & 0.7 \\
\hline Paper mulch & 5.6 & 39 & 0.8 & 0.3 & 0.5 \\
\hline Control & 5.2 & 28 & 0.9 & 0.4 & 0.5 \\
\hline \multicolumn{6}{|c|}{ Lockwood Farm Gardens } \\
\hline Leaf-mold 3" & 9.6 & - & 2.0 & 0.9 & 1.1 \\
\hline Leaf-mold 2" & 7.0 & - & 1.7 & 0.8 & 0.9 \\
\hline Leaf-mold $1 "$ & 6.7 & - & 1.6 & 0.8 & 0.8 \\
\hline Control & 4.5 & - & 1.5 & 0.7 & 0.8 \\
\hline
\end{tabular}

an additional $3 / 4$ lbs $10-10-10$ fertilizer per plot spread along the row. The corn rows, used for a second planting of fall crops of cabbage, cauliflower, and broccoli, were amended with an additional 1-1/4 lbs of 15-15-15 fertilizer and $1-1 / 2 \mathrm{lbs}$ limestone.

\section{Vegetables grown}

The vegetables grown were essentially the same in 1976 and 1977 and are common to Connecticut's backyard gardens. Yellow squash, butternut squash, snap beans, carrots, and beets were grown from seed; tomatoes, cabbage, broccoli, peppers, and eggplant were grown from transplanted seedlings; onions were grown from sets; and lettuce was grown from seed in 1976 and from transplanted seedlings in 1977. Some varieties were changed from 1976 to 1977.

Corn, which requires a large area, was not grown at the Day-Waverly Gardens. A plot plan showing the arrangement of vegetables and spacing between rows is found in Appen$\operatorname{dix} \mathrm{A}$. The spacing between rows was closer than recommended for Connecticut gardens (Conn. Ext. Serv., 1968) but the rows were arranged so that taller plants would not shade shorter ones.

\section{Cultivation}

All experimental plots were cultivated as needed to control weeds and to maintain a friable soil surface for maximum infiltration of water. Weeds within the rows were pulled by hand to eliminate competition between crops and weeds for water and nutrients.

\section{Irrigation and sampling for moisture}

The experimental plots became the focus of attention in the Day-Waverly Gardens. They were watered amply by neighboring gardeners as they watered their own plots. For one week in mid-summer 1976, the plots were not watered to allow the soil to dry deeply. Soil samples were then taken to estimate the moisture content at the wilting point. Samples were also taken 24 hours after a heavy rainstorm in August to estimate the water content at field capacity in each plot. The difference between the two measurements approximates the amount of water available to growing plants.

The plots at Lockwood Farm received irrigation if plants became severely wilted. However, only three irrigations were necessary in mid-summer. Soil samples were taken following heavy rains and during droughty periods to estimate moisture holding capacity of the plots amended with varying amounts of leaf-mold.

\section{Pest control}

Insect pests were controlled in all plots as needed. Diazinon drench was used to control cabbage maggots. Aphids and cabbage loopers were controlled with rotenone. Squash vine borer and bean beetles were controlled with some success with methoxychlor dust in 1976 but with poor control in 1977. Corn borers were controlled at Lockwood Farm with Sevin. Tomato hornworms were destroyed by hand when observed.

\section{Harvest}

All vegetables were harvested when they reached marketable size. Weights of all vegetables were recorded as soon as they were picked. The value of the produce was determined by retail prices at the date of harvest.

\section{RESULTS}

Leaf-mold had a pronounced effect on the moisture holding capacity, the $\mathrm{pH}$, and temperature of the soil. These factors influence germination of vegetable seeds and crop yields. The results of our experiments follow.

\section{Improved available moisture holding capacity}

The soil in the paper-mulched and control plots of the DayWaverly Gardens was 95 and $83 \%$ sand respectively. The texture of the former was a coarse sand; the latter, a loamy coarse sand. Table 3 shows less than 1 inch of water was retained at field capacity in the upper 6 inches of both of the plots. The amount available for plant growth was only 0.5 inch. Since many plants use as much as 0.2 inch of water per day, both plots become deficient in 2 to 3 days. The paper mulch plot was the sandiest of all plots and also contained the most stones. It appeared to have been part of an old gravelled driveway. Under these circumstances the water holding capacity was probably less than 0.5 inch, but the paper mulch improved it slightly. The greatest benefit of the paper mulch was reduction of weeds. This plot required little attention other than watering.

The plot covered with topsoil contained $72 \%$ sand and its texture was classified as a sandy loam. 1ts moisture holding capacity of 0.7 inch in the upper 6 inches of soil (a 3- to 4day supply) was 25 to $35 \%$ greater than in the native soil.

Although the mineral portion of the leaf-mold plot was nearly $90 \%$ sand, the organic fraction was 4 -fold greater than on the other plots. This organic matter held nearly 2 inches of water in the upper 6 inches; almost a 7-day supply, 1.3 inches, was available to plants. All crops grown on this plot resisted wilting 2 to 3 days longer after watering or rainfall than the crops on the other plots. The added moisture supply in the leaf-mold plot also increased the resistance of tomato plants to blossom-end-rot. Droughty conditions on the other plots increased the incidence of this 
physiological damage, which is caused by an imbalance between the water needs of the plant and the supplying power of the soil. However, during the 1977 growing season, tomato plants on all experimental plots amended with leafmold suffered some damage from blossom-end-rot despite the increased moisture holding capacity of the soil. Although addition of leaf-mold will not always prevent damage, it will lessen the damage.

The Yalesville fine sandy loam at Lockwood Farm has a moderate moisture holding capacity. Table 3 shows that the Yalesville soil holds 1.5 inches of water at field capacity in 6 inches of topsoil and can supply plants with about 0.8 inch of water, a 4-day supply. Addition of 3 inches of leafmold doubles the organic content of the Yalesville soil to $9.6 \%$. The amount of water held at field capacity increased $33 \%$ to 2 inches. The moisture available to plants increased 0.3 inch (a 1- or 2-day supply) in the plot amended with 3 inches leaf-mold. At lower rates of leaf-mold application, increases in available moisture were negligible. Thus, the benefits of leaf-mold to increase moisture to growing plants are less dramatic on fine sandy loams and loams than on loamy sands and sands.

\section{Soil temperature}

Soils amended with leaf-mold are dark in color. Thus, one would expect their temperatures to be higher because of high absorption and low reflectance of sunlight. The increase in moisture holding capacity of the soil and the slower conductivity for heat, however, offsets absorption, and temperatures are, in fact, cooler at 2.5 inches. At Lockwood Farm late morning temperatures at a 2.5 -inch depth on sunny days were about 3 to $4^{\circ} \mathrm{F}$ lower on the plot amended with 3 inches of leaf-mold than on the untreated plot. There were no temperature differences between the plots amended with 1 and 2 inches of topsoil and the control plot.

\section{Germination of seeds}

During a period of cool, wet weather in early May 1976 , deeply planted bean and squash seeds rotted in the leafmold plot and had to be replaced. Small, shallowly planted seeds germinated as expected. All seeds germinated well on the other plots, which were drier.
In 1977 we observed rates of germination on the Lock. wood Farm plots. Seeds were planted on May 12th. Small carrot, beet, and radish seeds germinated most rapidly on the control and 1-inch leaf-mold plots. Germination was delayed 3-5 days on the 2- and 3-inch leaf-mold plots and many seeds failed to germinate leaving gaps in the row. Gaps were replanted May 31. Germination of reseeded areas was prompt and complete except for beets on the 3 inch leaf-mold plot. On this plot, the final density of beets was only $75 \%$ of the density on other plots.

Germination of large seeds of summer squash and snap beans planted May 12 was poor in all plots. By May 26 only 45 to $68 \%$ of snap beans and 40 to $73 \%$ summer squash had germinated. Germination was best on the 3-inch leaf-mold plot and worst on the control and 1-inch leaf-mold plots. This was contrary to our observations in 1976. Since the Lockwood Farm plots had a higher moisture holding capacity than the sandy Day-Waverly plot, it appears that they warm slower in early spring. Clearly, the seeds were planted too early for complete germination in the Yalesville soil. In contrast, germination of corn seeds planted May 12 was better, ranging between $90 \%$ on the 3 -inch leaf-mold plot and $72 \%$ on the control plot. The improved germination of corn may be because the seeds were planted in hilled rows which may dry and warm faster than flat rows. Germination of second plantings of snap beans and corn in late May and June was rapid and met seed-bag standards.

\section{Effect of leaf-mold on soil $\mathrm{pH}$}

Leaves that have been composted at temperatures of 140 to $160^{\circ} \mathrm{F}$ where thermophyl]ic organisms predominate produce a compost rich in soluble salts with a $\mathrm{pH}$ of about 7.0 (Sawhney, 1976). Leaf-mold added to Yalesville fine sandy loam increased soluble salt contents to 520 parts per million in the 3-inch leaf-mold plot. This concentration of salts is less than the amount added in normal fertilization and presents no problems when added to field soils. The $\mathrm{pH}$ of the Yalesville soil (5.5) increased to 6.1 when 3 inches of leaf-mold were added and rototilled to a depth of 6 inches. Only $30 \mathrm{lbs} / 1000 \mathrm{ft}^{2}$ ground limestone were needed on the 3 -inch leaf-mold plot whereas $70 \mathrm{lbs} / 1000 \mathrm{ft} 2$ were needed on the control plot to raise the $\mathrm{pH}$ to the optimum level (6.5).

Table 4. Vegetable Yields-Day-Waverly Gardens-1976. Improvement of moisture holding capacity

\begin{tabular}{|c|c|c|c|c|c|c|c|c|}
\hline & \multicolumn{8}{|c|}{ Plot } \\
\hline & \multicolumn{2}{|c|}{ Leaf-mold } & \multicolumn{2}{|c|}{ Topsoil } & \multicolumn{2}{|c|}{ Paper mulch } & \multicolumn{2}{|c|}{ Control } \\
\hline & Ibs & $\begin{array}{l}\% \text { of } \\
\text { Control }\end{array}$ & Ibs & $\begin{array}{l}\% \text { of } \\
\text { Control }\end{array}$ & lbs & $\begin{array}{l}\% \text { of } \\
\text { Control }\end{array}$ & Ibs & $\begin{array}{l}\% \text { of } \\
\text { Control }\end{array}$ \\
\hline Snap beans & 3.0 & 81 & 5.4 & 146 & 3.2 & 86 & 3.7 & 100 \\
\hline Yellow squash & 5.4 & 47 & 28.3 & 248 & 6.9 & 60 & 11.4 & 100 \\
\hline Lettuce & 6.1 & 130 & 3.9 & 83 & 1.6 & 34 & 4.7 & 100 \\
\hline Beets (wo/tops) & 4.5 & 72 & 4.2 & 68 & 3.7 & 60 & 6.2 & 100 \\
\hline Carrots (wo/tops) & 7.2 & 122 & 5.7 & 97 & 4.1 & 69 & 5.9 & 100 \\
\hline Peppers & 5.0 & 238 & 3.0 & 143 & 2.8 & 133 & 2.1 & 100 \\
\hline Onions & 1.5 & 250 & 1.2 & 200 & 0.4 & 67 & 0.6 & 100 \\
\hline Tomatoes & 40.3 & 143 & 27.2 & 96 & 28.5 & 101 & 28.2 & 100 \\
\hline Eggplant & 13.8 & 134 & 9.4 & 91 & 5.8 & 56 & 10.3 & 100 \\
\hline Butternut squash & 3.8 & 58 & 1.9 & 29 & 8.0 & 123 & 6.5 & 100 \\
\hline
\end{tabular}

*Broccoli and cabbage also grown but rows were incomplete for comparison. 
Leaf-mold applied to mortar-laden sandy fill in the DayWaverly Gardens produced no changes in $\mathrm{pH}$ because both materials were about neutral (7.0).

\section{Yields of vegetables}

The yields of vegetables grown at the Day-Waverly Gardens in 1976 are reported in Table 4. The leaf-mold plot produced consistently higher yields. The harvest of peppers and onions was $240-250 \%$ of the yield on the control plot. Yields of lettuce, carrots, tomatoes, and eggplant were about 120 to $145 \%$ of the yields on the untreated plot. The yields of snap beans, yellow and butternut squash, and beets were less than the yields on the control plot. These lower yields were mostly due to poor germination in the wetter, cooler soil of early spring as previously described.

The yields of most vegetables on the topsoil plot were intermediate between yields on the leaf-mold and control plots. Only the yields of snap beans and yellow squash exceeded yields on the leaf-mold plot. The yields of vegetables on the paper mulch plot were generally a fraction of the yields on the control plot. Only the yields of peppers and butternut squash exceeded the yields of the control plot. This plot had the coarsest texture and the greatest volume of stones of all plots. While the paper mulch undoubtedly helped to conserve water, the amount of water still fell short of the requirements for satisfactory growth of vegetables.

The yields of vegetables grown in the fertilizer experiments in the Day-Waverly Gardens in 1977 are reported in Table 5. We report the data only from the three plots receiving 3 inches of fresh leaf-mold in 1977. Although vegetables were grown on the original leaf-mold plot of 1976 , it was used as a buffer because it was located next to a walkway. We have averaged the yields in the plots receiving two and three applications of fertilizer and compared them with the control plot receiving one application. Late maturing beets, carrots and peppers benefited from supple. mental fertilization. Broccoli benefited from supplemental fertilization because shoot growth was picked throughout the growing season. Cucumbers planted as a second crop following lettuce responded best to supplemental fertilization. The remaining crops, mostly early maturing ones, did not benefit from additional applications of fertilizer. Snap beans, yellow squash and lettuce were nearing maturity or

Table 5. Vegetable Yields-Day-Waverly Gardens-1977. Fertilizer experiments.

\begin{tabular}{|c|c|c|c|c|}
\hline \multirow[b]{3}{*}{ Snap beans } & \multicolumn{2}{|c|}{$\begin{array}{c}\text { Average of } \\
2 \text { and } 3 \text { Applications } \\
(1.3 \text { and } 1.8 x)\end{array}$} & \multicolumn{2}{|c|}{$\begin{array}{c}\text { Control } \\
1 \text { Application } \\
\text { (X) }\end{array}$} \\
\hline & Ibs & $\%$ of Control & Ibs & $\%$ of Control \\
\hline & 5.4 & 86 & 6.3 & 100 \\
\hline Yellow squash & 12.1 & 107 & 11.3 & 100 \\
\hline Lettuce & 9.8 & 96 & 10.2 & 100 \\
\hline Beets (w/tops) & 5.6 & 143 & 3.9 & 100 \\
\hline Carrots (w/tops) & 5.1 & 121 & 4.2 & 100 \\
\hline Peppers & 6.8 & 121 & 5.6 & 100 \\
\hline Onions & 1.1 & 58 & 1.9 & 100 \\
\hline Tomatoes & 21.8 & $67^{*}$ & 32.3 & 100 \\
\hline Eggplant & 14.7 & 102 & 14.4 & 100 \\
\hline Broccoli & 2.8 & 127 & 2.2 & 100 \\
\hline Cucumbers & 6.9 & 255 & 2.7 & 100 \\
\hline
\end{tabular}

*Severe damage by blossom-end-rot. harvested before the third application. Benefits from the third application in July were generally negligible.

The total yields of all crops at the Day-Waverly Gardens were about 10\% less in 1977 than in 1976. Most of this loss can be attributed to loss of yellow squash, which was severely injured by an early invasion of squash vine borers. Tomato yields were also down $25 \%$ due to blossom-end-rot. The increased moisture holding capacity of leaf-mold failed to fully protect our plots against moisture stress. However, we observed far greater losses on garden plots without leafmold.

Decreased yields of yellow squash and tomatoes were offset by increased yields of snap beans (45\%) and lettuce (150\%). Lettuce yields were superb because transplanted seedlings were used instead of seeds. The plants matured more rapidly and took advantage of cool, moist weather in early spring. The 1977 lettuce crop matured in mid- to lateJune while the 1976 crop, which was started from seed, had smaller heads as summer dryness set in.

The yields of vegetables grown at Lockwood Farm are reported in Table 6. The highest yields of yellow squash, lettuce, beets, carrots, tomatoes, eggplant, and swiss chard occurred on the 1 -inch leaf-mold plot. Total yield of all vegetables was $11 \%$ greater on the 1 -inch leaf-mold plot than on the control plot. Duncan's Multiple Range Test showed that these increased yields were statistically significant. Yields of broccoli, cabbage, and butternut squash were greatest on the 3 -inch leaf-mold plot. No vegetables had the highest yields on the 2 -inch leaf-mold plot. However, yields of lettuce, eggplant, broccoli, swiss chard, and butternut squash were higher than on the control plot. Total yield on the 2-inch plot matched the total yield on the control plot. Yields of peppers on all leaf-mold amend. ed plots were low. The prolific yellow squash crowded the peppers and successfully competed for water, nutrients and light.

It appears that 1 inch of leaf-mold helped produce consistently high yields for most vegetables. Since 1 inch of leaf-mold did not increase the moisture holding capacity of the Yalesville soil, its benefit is probably derived from improved friability. The Yalesville soil crusts following rains and reduces infiltration. Addition of leaf-mold undoubtedly reduces this tendency to crust.

\section{Yearly decomposition rates and maintenance of leaf-mold}

Leaf-mold worked into the soil continues to degrade due to the action of bacteria and fungi. Because the amount of leaf-mold in the soil decreases during the growing season, it is important to know how much is left for next year's crop. At the Day-Waverly Gardens 3 inches of leaf-mold added to the sandy builders' fill in 1976 increased the organic matter from 5 to $16 \%$. In 1977 the organic content of the leafmold plot decreased to $11 \%$. To maintain an organic content of about $15 \%$ in this sandy soil, it appears that annual addition of slightly more than 1 inch of leaf-mold is needed.

Addition of 3 inches of leaf-mold to the finer textured Yalesville soil increased its organic content from 5 to $10 \%$. At the end of the growing season, the organic content had 
Table 6. Vegetable Yields-Lockwood Farm-1977. Leaf-mold application rates.

\begin{tabular}{|c|c|c|c|c|c|c|c|c|}
\hline & \multicolumn{6}{|c|}{ Leaf-mold plot } & \multicolumn{2}{|c|}{ Control } \\
\hline & \multicolumn{2}{|c|}{ 3-inches } & \multicolumn{2}{|c|}{2 -inches } & \multicolumn{2}{|c|}{1 -inch } & \multirow[b]{2}{*}{ Ibs } & \multirow[b]{2}{*}{$\begin{array}{l}\% \text { of } \\
\text { Control }\end{array}$} \\
\hline$\cdot$ & Ibs & $\begin{array}{c}\% \text { of } \\
\text { Control }\end{array}$ & Ibs & $\begin{array}{c}\% \text { of } \\
\text { Control }\end{array}$ & lbs & $\begin{array}{l}\% \text { of } \\
\text { Control }\end{array}$ & & \\
\hline Snap beans & 15.1 & 85 & 13.4 & 75 & 15.2 & 85 & 17.8 & 100 \\
\hline Yellow squash & 117.0 & 110 & 107.1 & 101 & 117.1 & 110 & 106.1 & 100 \\
\hline Lettuce & 12.7 & 95 & 14.8 & 110 & 15.0 & 112 & 13.4 & 100 \\
\hline Beets (w/tops) & 7.8 & 58 & 13.5 & 101 & 16.0 & 119 & 13.4 & 100 \\
\hline Carrots (w/tops) & 14.0 & 93 & 13.4 & 89 & 21.6 & 143 & 15.1 & 100 \\
\hline Peppers & 1.2 & 32 & 1.9 & 50 & 2.3 & 60 & 3.8 & 100 \\
\hline Onions & 4.0 & 89 & 3.7 & 82 & 4.8 & 107 & 4.5 & 100 \\
\hline Tomatoes & 71.9 & 94 & 75.4 & 99 & 82.9 & 108 & 76.5 & 100 \\
\hline Eggplant & 10.8 & 127 & 9.0 & 106 & 12.1 & 142 & 8.5 & 100 \\
\hline Broccoli & 12.3 & 126 & 11.4 & 116 & 9.3 & 95 & 9.8 & 100 \\
\hline Cabbage & 20.0 & 116 & 14.4 & 84 & 15.7 & 91 & 17.2 & 100 \\
\hline Swiss Chard & 7.9 & 87 & 11.8 & 130 & 12.3 & 135 & 9.1 & 100 \\
\hline Butternut squash & 21.9 & 296 & 10.4 & 140 & 13.1 & 177 & 7.4 & 100 \\
\hline
\end{tabular}

*Corn, cucumbers also grown but suffered extensive raccoon damage. Weights of 2 radish crops were not recorded. Most of the fall cauliflower crop did not mature to permit comparison between plots.

decreased about $1 \%$. Annual addition of three-fifths of an inch of leaf-mold would be required to maintain the organic matter level at $10 \%$. However, approximately one-third inch could be added each year or 1 inch every 3 years because the greatest crop yields were realized at an organic content of $7 \%$.

\section{DISCUSSION}

\section{Planning for maximum yield}

Successful gardening does not come easy. Planning, planting, and perspiration are required. The garden plots at Lockwood Farm were planned for maximum yields. Spacing between rows was narrowed from recommended spacing (Conn. Ext. Serv. 1968). The spacing between yellow squash rows was narrowed from 36 to 24 inches. Bean rows were reduced from 24 to 12 inches apart. Beets, carrots, onions, and lettuce rows were set 12 inches apart, the narrower spacing of the recommended range. The narrow spacing allowed a greater variety of vegetables to be grown in the $30 \times 40$-foot garden. Crowding of some vegetables led to difficulties in hoeing weeds and harvesting. Despite crowding, yields were probably greater than average for Connecticut gardens. One useful space saver is planting butternut squash within rows of tomatoes. Since tomato plants were staked upright, there was sufficient room for the squash vines to run. The greatest competition for space was provided by yellow squash vines. Their yields were outstanding (Table 6) but the pepper plants in the adjacent row were stunted and their yield reduced. Planting tall crops behind shorter ones prevented shading in the afternoon and provided ample sunlight. Only cucumbers grown on a chickenwire fence at the rear of the plots were shaded by corn. Once the corn was harvested and the plants removed, the cucumbers grew rapidly. Gardens that are partially shaded by trees will produce tall, thin plants with generally reduced yields.

Planning for second crops is also worthwhile for maximum yield as well as staggered planting of crops to prolong harvest of a şingle crop. Bean and corn rows were planted 2 weeks apart in May and a late bean row followed an earlier one. However, yields of beans diminished with successive plantings. Our corn rows were replaced by late varieties of cabbage, broccoli, and cauliflower. Only the cauliflower failed to mature. Broccoli was picked to December 2 nd.

Because optimum moisture produces maximum yields, supplemental irrigation is necessary during the summer months.. Droughty soils can be made to hold more water by amending with leaf-mold. Fertility needs to be checked periodically so that deficiencies do not occur. However, delayed ripening of tomatoes may occur if nitrogen levels are too high in mid-summer. Competing weeds should be removed by cutting with a hoe or by hand pulling within rows. Most plant pests can be controlled as they appear.

\section{Economic value of a garden plot}

To estimate the economic value of vegetables produced on the garden plots we recorded the price of vegetables each week at a local market and determined the value of vegetables on the day of harvest.

In 1976 the Day-Waverly plots produced $450 \mathrm{lbs}$ of vegetables per $1000 \mathrm{ft}^{2}$, with an economic value of $\$ 213$. The greatest return was from tomatoes and yellow squash which accounted for nearly half of the value. Eggplant was also a high value producer. Maishe Dickman, garden coordinator of the Greater New Haven Arts Council, also maintained a record of his yields in 1976. The economic value of his crops per $1000 \mathrm{ft}^{2}$ was $\$ 218$. Although he did not use leaf-mold, he gave his plants considerably more water. In 1977, the total yield at the Day-Waverly Gardens plots was $410 \mathrm{lbs}$, a decrease of about $10 \%$ from the previous year. The value of the 1977 crops was $\$ 193$ per $1000 \mathrm{ft}^{2}$. Most of the yield decrease was at the expense of the tomato crop which suffered a $25 \%$ loss due to blossom-end-rot. Agricultural Statistics (1976) indicates that the annual per capita consumption of fresh vegetables is $143.2 \mathrm{lbs}$. Thus, we conclude that with proper care, $1000 \mathrm{ft}^{2}$ in the Day-Waverly Gardens can provide fresh vegetables for about 3 persons.

The plots at the Lockwood Farm yielded at the rate of $1120 \mathrm{lbs}$ of vegetables per $1000 \mathrm{ft}^{2}$ with an economic value 


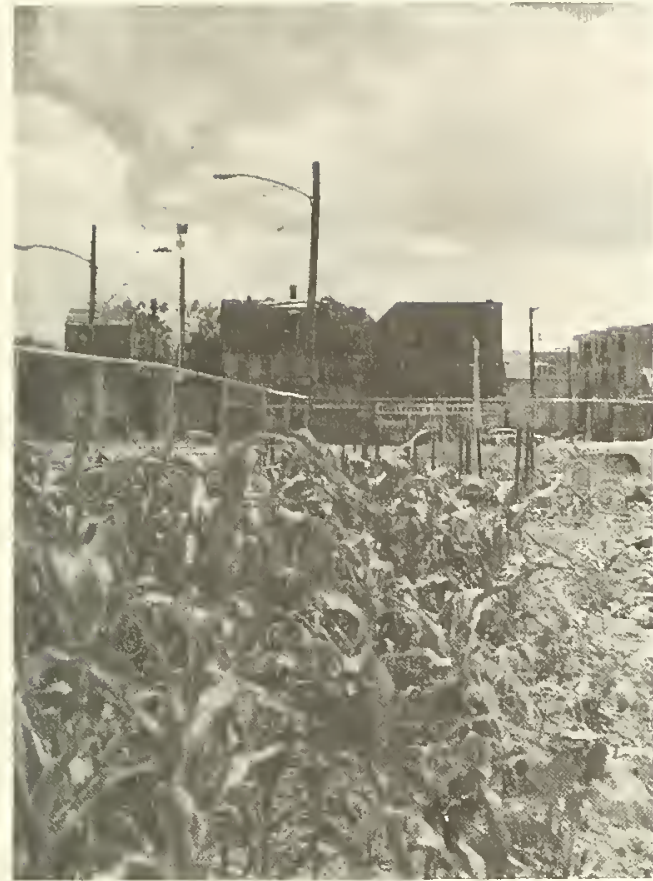

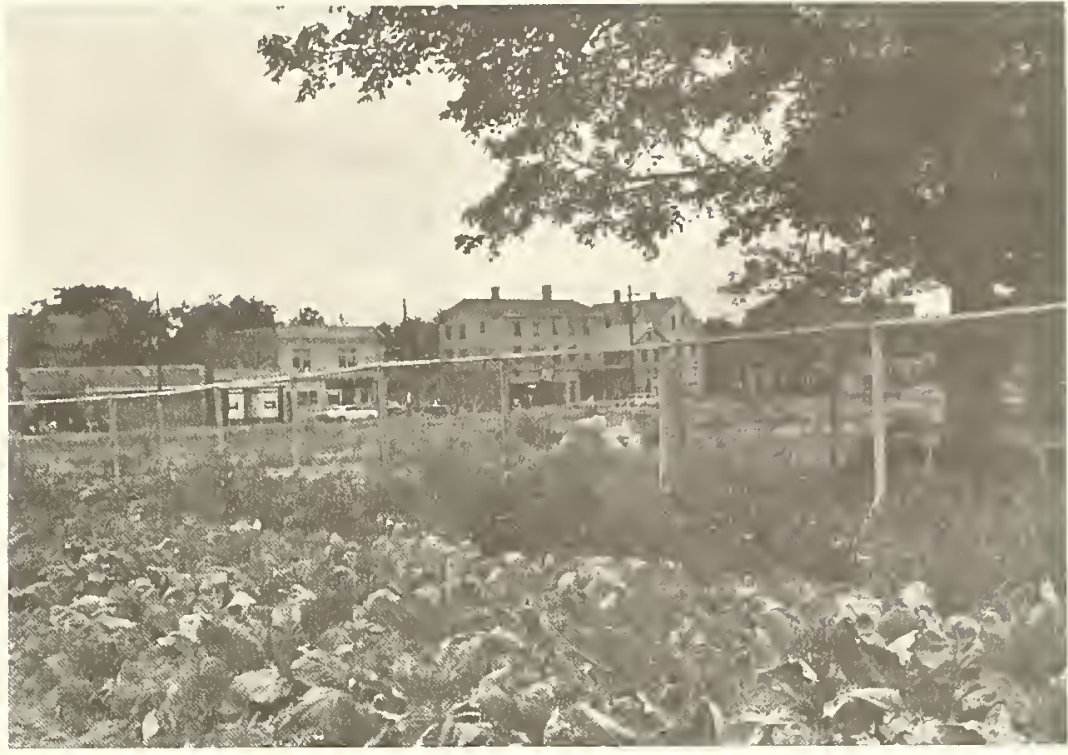

The Day-Waverly Gardens in Downtown New Haven. Corn at the left yielded 150 ears on a small plot, without the benefit of leaf-mold. Corn was not grown in the experimental plots because of the space needed for proper growth. At the right are collard greens and cabbages in a plot of one of the community gardeners. of $\$ 445$. This represents a 2.5 -fold increase in both 1 bs of vegetables and economic value over the Day-Waverly Gardens. Once again the greatest return was from the yellow squash and tomato crop, which accounted for about half of the cash value. Two crops of broccoli and corn and 3 crops of snap beans were also of economic significance. The Lockwood Farm plots produced enough vegetables to supply 9.5 persons, a 3 -fold increase over the Day-Waverly Gardens.

\section{CONCLUSIONS}

From our experiments using leaf-mold as an organic amendment to garden soils we conclude the following:

- Leaf-mold added to sandy soil significantly improves the moisture holding capacity and adds a 3- to 4-day moisture supply to growing plants.

- It adds cohesiveness to a very sandy soil, improves the structure of a fine textured soil, and reduces surface compaction following rains which allows greater infiltration.

- Leaf-mold produced by high temperature decomposition has a neutral $\mathrm{pH}$. It can help reduce the lime requirement for an acid soil.

- Three inches of leaf-mold added to soils of sand and loamy sand texture significantly improves vegetable yields. One inch of leaf-mold will suffice where textures are fine sandy loams or loams.

- Repeated applications of 1 inch leaf-mold each year can maintain suitable levels of organic matter in very sandy soils. One inch of leaf-mold can be added to fine textured soils about every third year.

- Leaf-mold has a low fertilizer value, but nutrient deficiencies often can occur as leaf degrading organisms compete with growing plants for nu- trients. About 25\% more fertilizer is beneficial when added late in June after the first flush of growth.

- Additions of leaf-mold may cause poor germination of seed in early spring, especially for large seeds planted deeply. A delay of planting by a week or two improves germination.

-With optimum fertilization and water, vegetables grown on a very sandy soil amended with leafmold can feed about 3 persons per $1000 \mathrm{ft}^{2}$. On a finer textured soil vegetable yields can feed 9 persons, a 3-fold increase.

\section{References}

Downs, D.B., Jacobson, H.G.M. and Waggoner, P.E. 1962. Rotations, organic matter, and vegetables. Conn. Agr. Exp. Sta. Circ. 220, 16p.

Havens, A.V. and McGuire, J.K. 1961. Climate of the Northeast: Spring and fall low-temperature probabilities. New Jersey Agr. Exp. Sta. Bull. 801, 31p.

Lunt, H.A., Jacobson, H.G.M. and Swanson, C.L.W. 1950. The Morgan soil testing system. Conn. Agr. Exp. Sta. Bull. 541, 60 p.

Sawhney, B.L. 1976. Leaf compost for container-grown plants. HortScience 11:34-35.

Trask, Owen S. 1968. Growing vegetables-4 H members guide. Conn. Extension Service, Univ. of Conn., Storrs, 7p.

U.S. Department of Agriculture. Agricultural Statistics-1976. U.S. Government Printing Office, Washington, D.C. 613p.

\section{ACKNOWLEDGEMENTS}

Mr. Maishe Dickman, coordinator for the Day-Waverly Gardens, deserves special recognition for his enthusiastic leadership on behalf of the Greater New Haven Arts Council. We are indebted to him for bringing this project to our attention and for his constant help throughout the study. 1 also wish to express my appreciation to Mary Alice Illig and Thomas Rathier for their capable technical assistance. 


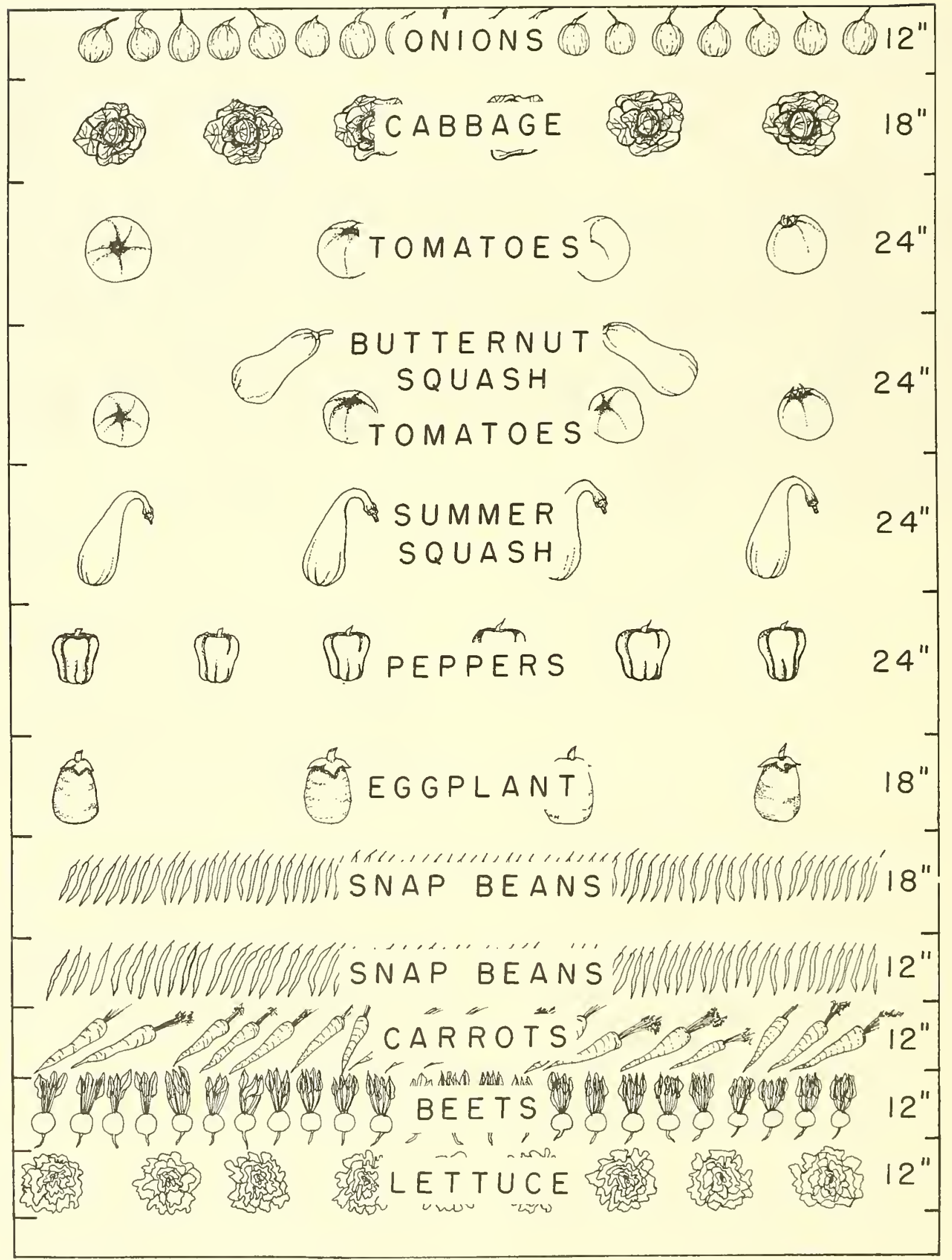

Appendix A. Planting Diagram for Day-Waverly Gardens. The number of cabbages, tomatoes, peppers, lettuce, and eggplants are as shown, as are the number of hills of yellow and butternut squash ( 4 plants per hill). Onions, snap beans, and beets were thinned to 3-inch spacing; carrots were thinned to 2 -inch spacing. Planting was identical for each of 4 plots. 



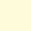


Libraries

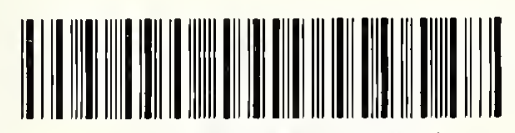

39153026970901 
